\title{
On Editing Troilus and Criseyde Now
}

\author{
Steve Guthrie
}

\begin{abstract}
This essay advertises an interactive online edition of Troilus and Criseyde designed to offer student readers in particular access to the poem and to Chaucer's Middle English without modernized spelling or translation. The essay describes the textual method of the edition and its approach to online publication and language instruction.
\end{abstract}

\begin{abstract}
Many years ago, I made a study of the text and language of Chaucer's Troilus and Criseyde as the basis for a metrical analysis (GuthRIE 1988). ${ }^{1}$ At the time, a new edition of the poem was a tempting thought, but two perfectly good and relatively new scholarly editions were available in John Fisher's Complete Poetry and Prose and Stephen Barney's text in Larry Benson's Riverside Chaucer. As these volumes increased in price, the thought returned, but Barry Windeatt's freestanding paperback edition of the poem became widely available in this country in 2003, and once again the ground seemed to be have been covered.

I returned to the idea a third time in the present decade because it seemed clear, even to an analogue mind more or less at sea in a digital age, that a real online edition of the poem could be useful to medievalists, and at the same time more useful to students, including Middle English language learners, than either a print edition or the currently available online texts, which were merely .pdf files scanned from older print editions. ${ }^{2}$
\end{abstract}

1. Detailed results of the study are in my unpublished 1985 Brown University dissertation, "Chaucer's French Pentameter".

2. Skeat and Robinson I are online now. There is also Murphy's modernized spelling edition, likewise in .pdf format, but it is unattributed and problematic as a study text. 
This essay describes my approach to a new online edition of the poem (Guthrie 2014). ${ }^{3}$ The edition is a step or two beyond the posted .pdf file, in that it uses internal links and mouseover notes, but these are relatively low tech devices by current standards, and the essay will not unveil any new digital technique or technology. Nor is it a theoretical discussion; it focuses mainly on familiar and relatively mundane strategic and tactical concerns that apply to print editions as well as electronic ones. In fact, one of my points is that, for this poem at least, the deeper questions have been not so much answered as exhausted, a happy accident that leaves an editor free to focus on more pressing needs.

In both respects - publishing medium and editing tactics - a primary goal of the edition is to serve the needs of current students as well as those of medievalists. Chaucer studies are at a crossroads, because access to Middle English language is at a crossroads. American English is changing rapidly, and American education in language and literature has changed substantially in recent decades. Chaucer is rarely included in secondary curricula now, and it is possible for most college undergraduates, even English majors, to avoid antique stages of the language entirely. It seems likely that by the end of this century, Chaucer will survive for most readers only in translation. In the meantime, if he is to remain a living presence in the larger culture (if only to inspire the occasional film costume drama) and not merely an antiquarian specialty, then his works must be accessible to the young, and this access will be difficult unless language instruction is somehow built into the edited text of the work, not merely consigned to the glossing of obsolete words and the introductory section on Middle English pronunciation and grammar. My approach to this problem, illustrated late in the essay, is to normalize the more obscure manuscript spellings to the more recognizable values of the base manuscript and, less often, the other principal early manuscripts of the poem. Normalizing diminishes over the course of the poem, so that by its end, a Middle English language learner is reading something close to the base manuscript. In this way, the tactic should be both a reading aid and a teaching device. ${ }^{4}$

3. The edition was formatted in .html by Tammy Roundy, web developer in the college's IT department. Part of the content of this essay appears in the introductory materials to the edition.

4. Another approach is offered online by the Harvard English Department, which gives interlinear translations of the Riverside Canterbury Tales (INTER LINEAR Translations 2010). These have been useful to beginning readers and have 


\section{Book One}

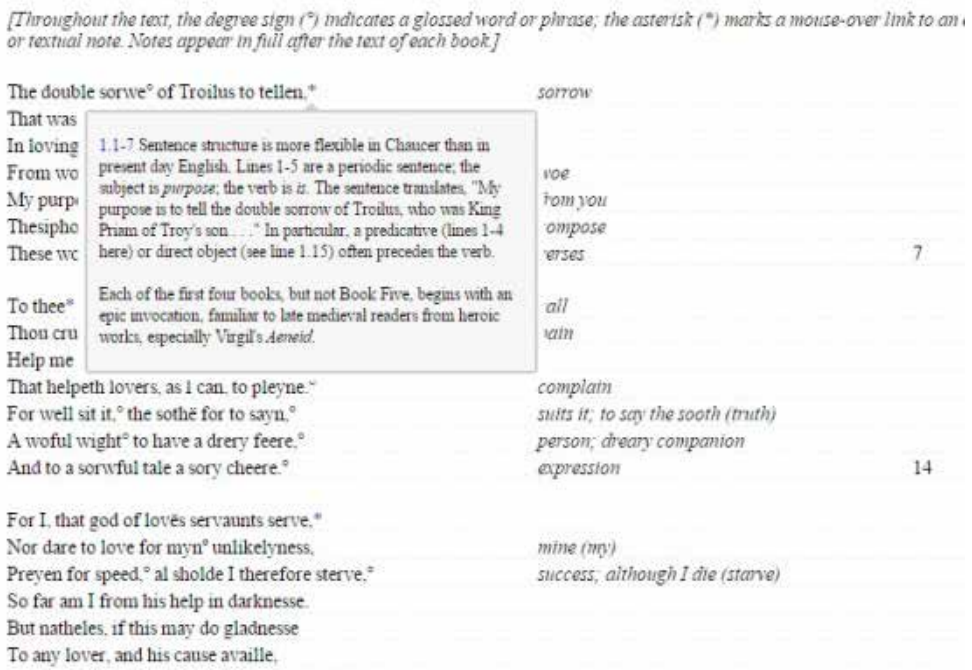

Plate 1. Screenshot of mouseover note

The edition also responds to the need for a study text which makes use of the resources available to online publication: free and open access, mouseover notes for instant navigation within the site, and quick and easy revision as need arises. A third object has been the same as for any print edition: to construct from the historical record a plausible text for the poem. The bulk of the present essay focuses on this aspect of the editing process, which includes my approach to Middle English language instruction. As mentioned, the prospect of online publication was the real motive for the project, but the advantages of the medium will be obvious and quick to describe, and the bulk of the work of editing, whether the product is physical or virtual, is the establishment and explanation of the text.

Troilus and Criseyde was almost certainly written in the 1380s; it is a poem of 8239 lines and roughly 60,000 words, about the length of a modern novella, written in the virtuosic seven line lyric stanza called rime royal. It is more than three times as long as the Knight's Tale, the longest of

even seemed to help a few of my students learn Middle English, but they add a layer of language between the student and the poem. 
the Canterbury Tales, and almost half as long as the combined length of the poetic tales of Canterbury, and it is the only major work that Chaucer completed. A modern edition of the poem belongs to a tradition that dates back to 1933 (Robinson) or 1894 (Skeat) or 1881 (Furnivall) or 1866 (Morris) or 1854 (Bell) or 1775 (Tyrwhitt, whose edition did not include this poem but who was the first modern editor to understand Chaucer's language and versification) or 1721 (Urry) or 1561 (Stowe) or 1532 (Thynne) or 1483 (Caxton), ${ }^{5}$ or even to the early fifteenth century, when scribes often juggled manuscripts to patch gaps in the text or substituted familiar words or spellings for obscurities in the text they were copying from (ADAms 1991, 9). ${ }^{6}$ It is a truism, but a new edition is a part of history and owes much to the past.

At the same time, any edition is an interpretation of the poem for the present, focused through the lenses of the present. It will, and should, reflect its times. Ninety years ago, this statement would have seemed misguided: the object of editing Chaucer was to reach through the obvious gaps and biases of history toward the original poem as the poet wrote it. In the early twenty-first century, a sufficient objection to this goal is that Chaucer's poem is unrecoverable. His older French contemporary Machaut left autograph manuscripts, but the earliest extant manuscripts of Troilus and Criseyde are probably from about fifteen years after Chaucer's death, and it has been impossible to establish a manuscript genealogy or a reliable record of the poet's process of composition. It is still possible to do what we can with what we have - the manuscripts and the early print record of the poem, and our knowledge of Chaucer and of late medieval manuscript transmission - and to arrive at a readable text that approaches the poem as it probably existed in the 1380 s. In this way, an editor's job is the same now as in the early twentieth century.

Troilus and Criseyde survives in sixteen manuscripts, none earlier than about 1415, another handful of manuscript fragments, and three early print editions (by Caxton, Thynne, and de Worde) often given manuscript standing by editors. Four manuscripts are superior, in terms of complete-

5. Root gives a useful description of the editorial tradition prior to his edition (1926, 1xi-lxx).

6. Kane hypothesizes a more intentional process of scribal revision for the A-Text of Piers Plowman, arguing that the investment of scribes in the religious content of the work would explain such attention $(1960,115)$. There is no clear evidence of a similar attentiveness in the manuscript tradition of Troilus and Criseyde, but the emotional investment of Chaucer's clerkly narrative figure in the love plot of the poem is suggestive. 
ness, coherence, and plausibility. Three of these are from the early fifteenth century: Corpus Christi College, Cambridge number 61 (the one with the frontispiece of probably Chaucer reading possibly this poem to a court audience); Campsall (now Pierpont Morgan Library 817); and St. Johns College, Cambridge ms. L.1. The fourth, Harleian 2280, from the mid-fifteenth century, closely resembles Corpus. ${ }^{\text {? }}$

William McCormick (the Globe editor) argued for three stages of composition and three manuscript types, $\alpha, \beta$, and $\Gamma$, with $\Gamma$ the finished product (Root 1926, lxx note 142). Corpus, Campsall, and Harleian 2280 are type $\Gamma$; St. John's is $\beta$ to line 4.430 and $\alpha$ from there to the end. R. K. Root, who had been McCormick's student, completed McCormick's manuscript study, and his own edition made $\beta$ the finished product, possibly because $\beta$ manuscripts looked to him like $\Gamma$ manuscripts with another layer of revision, consisting partly of patternless changes and partly of several transposed passages. ${ }^{8}$ For both, the stages-of-composition hypothesis satisfied the need for genealogy and made it possible to edit by recension. Root used twin base texts, St. John's and Corpus, correcting the $\alpha$ section of St. John's by Corpus and making Corpus his first resort for problems in St. John's in books One through Three (1926, 1xxxi-lxxxiii).

Robinson $(1933,1957)$ worked from Corpus, rejecting Root's $\beta$-as-endproduct theory but without a principled explanation (1957, xl). Root's influence is clear in Robinson's text, which frequently emends Corpus by St. John's, mainly on metrical grounds. Baugh's text (1963) is similar to Robinson's. Donaldson (1958) and Howard (1976) worked from Corpus. Fisher (1977) used Campsall, which by then had come to the U.S. as Pierpont Morgan Library Manuscript M. 817. To that point, no one had refuted Root's genealogy, but no one appeared to like its practical consequences for the text of the poem. In 1982, Windeatt offered a principled objection to the $\beta$ theory, pointing out that even a clearly demonstrable manuscript tra-

7. Root 1914 gives descriptions and photographic specimens of the manuscripts. Root 1916 gives detailed descriptions of the manuscripts and his argument for their genealogy. References here will use his shorthand, as follows. The principal manuscripts are Corpus Christi (Cp); Campsall / Pierpont Morgan (Cl); St. John's (J); and Harleian 2280 (H1). The two volumes of the Chaucer Society transcriptions (FurNivall 1881 and 1894-95) include two additional manuscripts: Cambridge Gg.4.27 (Gg), and Harleian 1239 (H3). The other manuscript specifically cited here is Rawlinson (R), the only manuscript that is type $\beta$ throughout.

8. See Root 1926, lxxi-ii. Hanna 1992 offers a plausible hypothesis for the process of transposition. See the discussion following. 
dition is not necessarily a stage of authorial composition (3). ${ }^{9}$ Barney (the Riverside editor) and Windeatt both followed Corpus. (Barney's readings do sometimes disagree with Robinson's, and when they do, they are usually closer to the base manuscript.)

Then in 1992, Ralph Hanna carried Windeatt's work farther, offering a plausible scenario for the $\beta$ tradition. On circumstantial but compelling evidence, Hanna argues that it is misleading to speak of three manuscript types and impossible to draw a stemma: $\beta$ is a real manuscript tradition, but only $\Gamma$ is anything like a real tradition of the poem. Type $\alpha$ consists of two extant manuscripts and parts of others, pointing to a hypothetical early archetype probably two removes from Chaucer; and type $\beta$ is historically real but poetically a mirage, an accident of late medieval commercial book production. $\beta$ scribes received the text piecemeal from a clearing house (182-83), in bound or loose quires, and the gaps, transpositions, and shifts of allegiance in the manuscripts occur in units of four, five, or eight stanzas or their multiples: quarto or folio page or quire (175-76). A leaf is missing or reversed, and there is a gap or transposition in the copy. The wrong quire arrives, and the copy changes allegiance. A delivery is late, and the scribe resorts to an inferior backup. By the late fifteenth century, a series of such events became a hodgepodge exemplar, and Caxton's edition set it in type (185-86).

Hanna's work ought to have been a methodological breakthrough, but it mainly justified the instincts of scholars, who, again, had dismissed Root's theory even before Windeatt's analysis gave them a reason to. And the work ought to have had wider implications for editing theory, but it was published while medieval studies was busy absorbing poststructuralism. So Hanna's article neither inspired nor inconvenienced most people, because by then not many people were particularly moved to recover Chaucer's intention or particularly troubled by the loss.

What remains for the present-day editor is either George Kane's monster eclecticism or best-text editing. Troilus and Criseyde is not a good candidate for Kane's method, for one important reason. Heavily eclectic editing is risky, but it is easy to understand why it would appeal to an editor of Piers Plowman. ${ }^{10}$ But with Troilus and Criseyde, the aggregate text is a

9. WindeAtt 1982 calls Root's designation of $\Gamma$ as the intermediate stage "an unhappy illogicality" (3), but Root had simply kept and transposed McCormick's labels.

10. See KANE 1960, 115-72 for a full explanation of his method, which rejects both recension and the notion of a base text and instead constructs each line from the full manuscript record. 
much different thing. Considering the means of transmission and the scale and speed of language change in the fourteenth and fifteenth centuries, the manuscripts are really remarkably consistent. There are hundreds of decisions to make about individual lines, and these are all consequential, in other words worth the effort of constructing an edition. But most of them are not essential to most readers of the poem. In the whole poem - if we set aside omissions, transpositions, dialect spellings, metrical hiccups, plausible synonyms, and other well-attested scribal tics - there are sixteen consequential variants: sixteen places where the choice of manuscript can radically affect the reading of a line. ${ }^{11}$ But any critical interpretation resting on the reading of one of these lines would be unbelievable, and any interpretation resting on any combination of them would be nonsensical; there is just no pattern there.

A few illustrations will suggest the scope of the variation. For line 3.391, Campsall and three other manuscripts, including the $\beta$ type Rawlinson, have the following:

Right as thy knave, whider so thou wende $(\mathrm{Cl}$, etc.).

(In Campsall, knave is corrected from sclave.) The other manuscripts, and all other modern editions, including Root, have the following:

Right as thy sclave whider so thow wende (Cp, etc.).

Chaucer's poem has departed from Boccaccio's at this point, so the Filostrato is no help. Lyric tradition in the 1580 s might prefer sclave, but not in the 1380s. It is hard to say, as it often is, which word the principle of the durior lectio would prefer (AdAms 1991, 8). ${ }^{12}$ The MED has only one citation for slave earlier than Chaucer's line (Southern Legendary, Beckett, c. 1300); and the next citation after Chaucer's line is from 1440. The TatlockKennedy Concordance has one entry for slave, this line; so if the word is Chaucer's, it is very much the harder reading. I have adopted knave, with a note calling attention to the issue. But it is difficult to see the line as a crux of the poem.

11. A list of these lines appears in an appendix.

12. His illustration is from Kane's discussion of a crux in Piers Plowman, but it has a general application. WindeAtT 2003 (lxii) and BARNEY 1987 (1162) explicitly state their reliance on the principle. 
In three places, manuscripts differ over pite and piete(e). The Corpus reading is the top line in each case.

4.246 His eyen two for pite of herte (Cp, H1, Gg);

Hise eyen two for piete of herte $(\mathrm{J})$

Hys eyen two for pite of his herte $(\mathrm{Cl})$

5.451 For evere in on his herte pietous $(\mathrm{Cp})$

ffor evere in oon his herte pietus $(\mathrm{J})$

For evere in oon his herte pitous $(\mathrm{Cl}, \mathrm{Gg})$

5.1598 Conceyved hath myn hertes pietee (Cp, J)

Conseyved hath myn hertes pitee $(\mathrm{Cl}, \mathrm{Gg})$

In all three lines, the issue is syllable count; in the last two of the above lines, readings with pitee / pitous are suspect because short one syllable. In line 4.246, however, either reading is plausible. Did the Campsall scribe (or someone before him) add his to fill out the line, or did the St. John's scribe change pite to piete for the same reason? MED senses for the two words current in the fourteenth and fifteenth centuries overlap considerably; each word is defined by the other. In two of the three lines, modern editing can make a plausible attempt at the textual problem, but this will not unravel the semantic question, except by recognizing that it seems to have existed in the early fifteenth century as well.

Most of the sixteen variants are similarly benign, but three are potentially more consequential, or just more interesting.

The first of these is $1.234-35$, for which Corpus and three minor manuscripts have

To serven love which that so soone kanne

The fredom of youre hertes to him thralle.

Other principal manuscripts, and all other modern editors, have "To skornen love ...". But the couplet at the end of the stanza clearly justifies the Corpus reading:

For love is he that alle thing may bynde

For may no man fordo the lawe of kynde

Fisher, working from Campsall, has a right to skornen, but the Corpus editors who run to Campsall here are taking a premature peek at the answer 
book by reading into the line the surface meaning of the poem's tragic ending.

The second is line 5.382:

As ravenes qualyn or schrichyng of thise owles (Cp; J qualin; R qualine)

As ravenes qualm or shrichyng of thise owles (Robinson, etc.)

The line is interesting because it sheds light on twentieth century editorial practice. Corpus Christi, a $\beta$ manuscript, agrees substantially with St. John's, a $\beta$ manuscript, and Rawlinson, which Root identifies as the only manuscript to belong to group B throughout (Root 1926, lix). So there is substantial agreement between important $\beta$ and $\Gamma$ manuscripts. Other principal manuscripts have qualm, and all modern editions except the present one adopt that reading. Robinson cites the MED, which defines qualm as the cry of a raven but cites only this line, a circular argument. ${ }^{13}$ Editors have preferred the monosyllable on metrical grounds, and the cadence (an extrametrical syllable at the caesura) is rare in Chaucer but not inconsistent with his metrical system. And qualyn is both grammatically appropriate and onomatopoetic.

The third consequential variant is line 5.1809, which has Troilus rising after death:

Up to the hologhnesse of the seventhe spere ( $\mathrm{Cp}, \mathrm{Cl}$, etc.)

Into the holwenesse of the viij speere $(\mathrm{J})$ $\ldots$ viijthe spere $(\mathrm{R})$

Up to the hologhnesse of the eighthe spere (Robinson, etc.)

Corpus, Campsall, and all but two other manuscripts have Troilus rising to the seventhe spere after death. St. John's and Rawlinson (both $\beta$ at this point) have viij spere and viijthe spere in Roman numerals. All modern editors emend to eighthe. The source here is Boccaccio's Teseida (Book 11, stanza 1), which has ottava (Roncaglia 1941). A great deal has been written on the line, much of it unnecessary. Explanatory notes in modern edi-

13. At this distance, it is easy to see the limitations of Root and Robinson, but every new edition builds on their work, and the fact that the present industry standard for the complete works, the Riverside, is a revision by many hands of Robinson's work, and is commonly known as Robinson III, says enough about Robinson's importance to the editorial tradition. 
tions justify eighthe on several grounds: the stanza closely resembles the parallel passage in Boccaccio; the scribal process viijthe $>$ vijthe $>$ seventhe is understandable; and eighthe puts Troilus in the sphere of the fixed stars, which makes more sense than the sphere of Saturn. And counting outward from earth in this way is consistent with Book 3, line 2, which places Venus at the third sphere.

In the same notes, the same editors also have reservations. There is the unanimous testimony of $\Gamma$ manuscripts for a start. And medieval reckoning is inconsistent: if we count inward from the primum mobile, depending on where we start, Troilus could pause at the sphere of Venus or the moon, either of which could make sense-Venus given the plot of the poem, and the moon as the first vantage point above the sublunary world. There is, however, a strangely ignored piece of evidence within this very passage. From his temporary vantage, Troilus sees

... with ful avysëment

The erratik sterrës herkenyng armonye (5.1811-12).

In other words, he looks down and sees the planets beneath him - all of them, apparently - and then he looks down farther to "This litel spot of erthe" (5.1815). And the only place from which he could do all this is the sphere of the fixed stars. This is one of the very few lines for which the present edition goes against the base manuscript on semantic grounds.

All in all, then, the manuscript record gives us a relatively uncontroversial text on which to base criticism of the poem. Given this situation, the logical course for an editor is to choose a $\Gamma$ manuscript and stick with it as far as possible. I chose Corpus because the Parkes-Salter photographic facsimile (1978) was available when I started to work with the poem. (A facsimile of Campsall was published by Jeanne Krochalis in 1986.) I used the facsimile to correct the Chaucer Society transcription of Corpus (Root found 20 errors in it; I found 114) and worked from that, consulting the other Chaucer Society transcriptions, ${ }^{14}$ a facsimile of Thynne's edition, ${ }^{15}$ Root's collations (1926), and the other modern editions, starting with Skeat.

The first question is when to desert the base text. There are 128.5 lines missing from Corpus; I supply these mainly from Campsall, with St. John's

14. See Furnivall 1894, 1894-95.

15. See Brewer 1974. 
as next resort. Apart from these missing lines, most departures from the base manuscript in previous editions of the poem are of two kinds: the correction of apparent scribal error or eccentricity, and the correction of lines that are metrically defective or anomalous or just annoying to the editor. Robinson in particular has a late Victorian ear for metrical regularity and little tolerance for metrical resolution or extrametrical syllables. ${ }^{16}$ But every modern editor sometimes deserts his base text on grammatical and metrical grounds. Robinson, for example, corrects ungrammatical manuscript spellings to more appropriate late fourteenth century values $(1957,906)$. In this he is typical of late Victorian and modern editors, and the impulse to make things right is understandable, but its value as a restorative is questionable: actual medieval grammar is never as clean as our grammarians make it look, any more than modern grammar is.

In a very few places, my edition also deserts its base manuscript on metrical grounds, where Corpus is clearly outside Chaucer's metrical system because of an obvious omission or interpolation; but in most places I leave the line as in the manuscript, even where the anomaly is surely scribal, in order to put the metrical system in perspective by letting the reader hear the consequence of its occasional breakdown. Overall, my edition is more conservative - closer to the base manuscript - than recent editions except possibly Fisher's. Barney and Windeatt are similar, and both emend at times on metrical grounds. Barney (1162) says that his edition is more conservative than Robinson's, which matches my informal comparison of the two. In the semantically variant lines discussed above, Windeatt's and Barney's readings agree.

The second question is how and when to modernize the text. Modernize has been a fightin' word among Chaucerians, but every editor does it. ${ }^{17}$ If you want an unmodernized text, read the Parkes-Salter facsimile. If you want a relatively unmodernized print text, read the Chaucer Society transcriptions. Modern editors change $u$ to $v$ and vice versa, change $f f$ to $f$, add phrase and sentence punctuation, capitalization, and quotation marks, and

16. See for example the discussion of line 5.382 above.

17. I was in the audience at the Medieval Institute Congress session in which Michael Murphy first advertised his modernized spelling edition of The Canterbury Tales sometime in the 1990s. He was met first by a restless silence and then by hortatory questions that were more nearly proclamations of distress. Murphy's editions are problematic, but not because of the modernizing. 
selectively normalize or modernize spelling, all of which alter the text. ${ }^{18}$ Editors sometimes disagree on where a sentence ends (there is no pointing in Corpus), and this too can affect the meaning of a passage. Donaldson mentions Chaucer's tendency to leave major phrases suspended ambiguously between sentences (1958, iv), a technique that postmodern poets tend to think they invented. When this happens, editors punctuate to disambiguate. So, again, the question is not whether or not to modernize but where to stop. Where is the line between best-text editing and eclectic editing? Hanna argues that any edition of Troilus and Criseyde is eclectic, simply because no manuscript is complete $(1992,174)$; and Tom Farrell has suggested to me that any semantically based intrusion on a base manuscript betrays the soul of an eclecticist. ${ }^{19}$ I see the point, but if we grant it, the label is redundant; any edition except a photographic manuscript facsimile is eclectic.

My object has been to produce an edition that will be useful to scholars but also accessible to twenty-first century undergraduates, including those with no prior experience of Middle English, which these days means almost everyone. Unfamiliar nouns and verbs are a problem, and even the most familiar function words may be unrecognizable. Donaldson says he tries to avoid spellings that would be unrecognizable to Chaucer (iii-iv). Donald Howard normalizes, apparently to the values of Middle English generally (1976, xxxv-xxxvi). My first inclination was to modernize, and I have nothing against the tactic in principle; Shakespeareans have long embraced it. Apart from the Oxford Original Spelling edition, modern editions of Shakespeare, including those used by most scholars, modernize spelling throughout. ${ }^{20}$

It quickly becomes clear, however, that modernized spelling is unnecessary for Troilus and Criseyde, and that even Donaldson's level of normalizing

18. Fisher 1977 succinctly lists the universal practices of modern editors and describes his own conservative approach to a text based on Campsall (966-68). His conservatism paid off; of the modern editions, his best captures the flavor of its base text. This may partly be due to the quirkiness of the manuscript, but it is partly Fisher's achievement, and his edition deserves respect for stepping outside the circle of Corpus editors to begin with.

19. Thomas J. Farrell, personal communication, tongue possibly in cheek, October 18, 2014; and see his essay in this collection.

20. It is true that the greater distance from Present Day English makes modernization more consequential for Chaucer than for Shakespeare, but by the same token, there is even less need to modernize Shakespeare. 
is unnecessary. It is possible to produce an accessible text by normalizing the more obscure spellings of a few function words, and a few dozen common nouns and verbs, to values that appear elsewhere in Corpus, and the spellings of another few dozen words to values attested in the other principal manuscripts. Altogether, the process involves about five per cent of the poem's vocabulary. In the case of one word, the second person pronoun the, my edition substitutes a modern spelling not authorized by the four principal manucripts, in order to avoid confusion with the definite article. (Thee does appear in Harleian 1239, but the manuscript is relatively late and often muddled. It would, however, repay further study as a way of gauging the pace of fifteenth century language change.)

Normal editorial practice in the past has been to gloss major class words and leave students to fend for themselves with the grammatical connective tissues. But sentence meaning depends on function words and syntax, and to a new reader, the density of function words and basic verb forms can make a page of text look like an optometrist's chart. It is impractical to gloss these often enough to fix the antique spellings in the mind of a Middle English language learner. And even if it were practical, the tactic would not help the student find a rhythm as a reader. It is impractical, particularly in a survey course, to spend enough time on language at the beginning of the term to solve the problem completely. But it is practical to substitute eye for ye, see for se, alle for al, such for swich, lieth for lith, thenne for than, and pitee for pite (which looks like /part/ to a modern eye), or to use hir for the feminine singular pronouns and hire for the genitive plural form. The spelling her appears occasionally in Campsall, but hir is intelligible, and it keeps the edited text closer to Corpus and to normal early fifteenth century spelling.

This normalizing does somewhat oversimplify late Middle English grammar and phonetics, but (a) these are well-attested manuscript spellings; and (b) anyone unable to follow the poem will miss the finer grammatical points anyway. For the rest of the vocabulary, I have let Middle English be Middle English. I have not aimed at spelling consistency, as Donaldson and Howard systematically did and as other editors have done, intentionally or not, to greater or lesser degrees.

My normalizing is heaviest at the beginning of Book One; it gradually thins out over the course of the poem, until, by the last half of Book Five, even a beginning student is reading something close to a transcription of Corpus. In other words, again, the normalizing is intended to be both a reading aid and a teaching tool. 


\begin{tabular}{|c|c|}
\hline 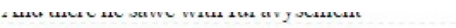 & san wowny \\
\hline The erratik sterrës ${ }^{\circ}$ herkenyng armonye, & the planets \\
\hline With sownës ${ }^{\circ}$ ful of hevenyssh melodie. & sounds \\
\hline And down from thennës faste he gan avyse ${ }^{\circ}$ & to regard \\
\hline \multicolumn{2}{|l|}{ This litel spot of erthe, that with the see } \\
\hline \multicolumn{2}{|l|}{ Embracëd is, and fully gan despise } \\
\hline \multicolumn{2}{|l|}{ This wrecched world, and held al vanitee } \\
\hline To respect of ${ }^{\circ}$ the pleyn felicitee & compared to \\
\hline \multicolumn{2}{|l|}{ That is in hevene above; and at the laste, } \\
\hline \multicolumn{2}{|l|}{ There he was slayn his lookyng down he caste, } \\
\hline And in hymself he lough ${ }^{\circ}$ right at the wo & laughed \\
\hline \multicolumn{2}{|l|}{ Of hem that wepten for his deth so faste, } \\
\hline \multicolumn{2}{|l|}{ And dampnëd al oure work that foloweth so } \\
\hline \multicolumn{2}{|l|}{ The blyndë lust, the which that may nat laste; } \\
\hline \multicolumn{2}{|l|}{ And sholden al oure herte on heven caste. } \\
\hline \multicolumn{2}{|l|}{ And forth he wentë, shortly for to telle, } \\
\hline \multicolumn{2}{|l|}{ Ther as Mercurye sorted hym to dwelle.* } \\
\hline Swich fyn ${ }^{\circ}$ hath lo this Troilus for love; & such end \\
\hline \multicolumn{2}{|l|}{ Swich fyn hath al his gretë worthynesse; } \\
\hline \multicolumn{2}{|l|}{ Swich fyn hath his estat real above; } \\
\hline \multicolumn{2}{|l|}{ Swich fyn his lust; swich fyn hath his noblesse; } \\
\hline Swich fyn hath falsë worldës brotelnesse. ${ }^{\circ}$ & brittleness \\
\hline \multicolumn{2}{|l|}{ And thus began his lovyng of Criseyde, } \\
\hline As I have told, and in this wise he deyde. & \\
\hline
\end{tabular}

Plate 2. Screenshot of the text late in Book Five.

Glossing is also relatively heavy at first, and glosses are in the right margin, where they are easy to absorb into the flow of reading. Whenever possible, a gloss connects a Middle English word to a present-day descendant. Glosses also clarify syntax when space permits, and notes extend the discussion in some places. The edition marks reduced final and medial $e$ by the diaresis, the same mark used by Tyrwhitt. Otherwise, there is no phonetic marking other than spelling.

In the explanatory and textual notes, I have tried to make the commentary intelligible to student readers as well as useful to medievalists. I have avoided technical terms when possible, and when that is not possible, I have tried at least to define the terms in place. In the documentation of Chaucer's sources, for example Ovid, Benoit, and Boethius, I have cited English translations or (for classical sources) facing-page translations. In one way I have tried to go beyond, or behind, other modern editions. The presence of a distinguished editorial tradition has sometimes encouraged the cloning of information. With respect to the text, see the discussion of line variants above. With respect to the notes and commentaries, 

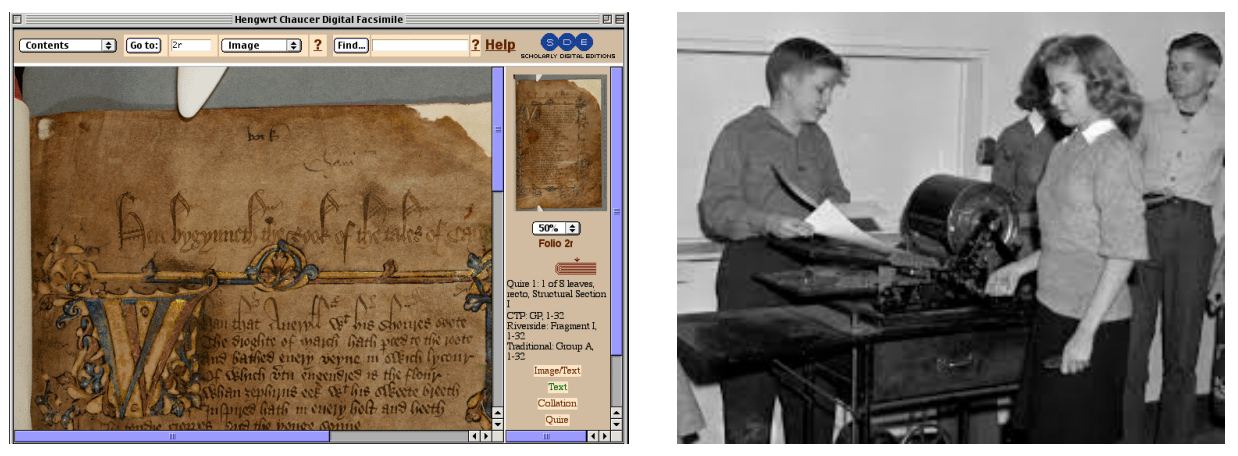

Plate 3. The new (left) and the old.

whenever possible I have checked oft-repeated views against their source materials. For example, Robinson's explanatory notes include a table of line correspondences between Troilus and Criseyde and Boccaccio's Filostrato, the primary source of Chaucer's poem $(1957,813)$. The same table is repeated exactly by Barney, the Riverside editor $(1987,1024-25)$ and Windeatt $(2003,349-50)$. The table is generally accurate, as far as it goes, but imprecise: it fails to distinguish between passages with close line-to-line correspondences, passages with less direct verbal relationships, and passages with only general plot similarities. The editions in question often do clarify the relationship between texts by means of individual notes, but the table overstates the kinship of the two poems. I have preferred to omit a table, describing the relationship between poems in the introductory materials and adding either brief or detailed explanatory notes as needed on specific passages.

The processes described to this point would apply equally to a print edition, and it is worth re-emphasizing that, while the project was motivated by the prospect of online access for readers, it has been justified by the oldfashioned drudgework of establishing a text. The advantages of electronic publication will be clear; the most obvious are open access and cost. A physical advantage is that explanatory notes can be done as mouseovers, keeping the reader-especially the beginning student reader-close to the text and giving the Middle English learner an added incentive to make use of the notes. Another advantage is the "Find" function in Word, which allows a reader to trace the progress of an image, theme, or character through the poem. A further advantage for both reader and editor is ease and speed of revision, as new critical issues and sources enter the discussion or as responses to the text suggest the need for additional notes or glosses. 
Despite these advantages over the printed book, my edition is extremely plain by the standards of current technology. The Scholarly Digital Editions facsimile of the Hengwrt manuscript of the Canterbury Tales, for example, gives the reader a strong sense of even the physical texture of the manuscript page, and it offers linked collation with the Ellesmere manuscript, aided by mouseover commentary. For the modern scholar, such editions are the shining city on the hill. The present edition of Troilus and Criseyde, by contrast, is more like the mimeograph machine in the church basement, but it is functional. Its hope is to attract young readers in particular - people who have never seen a mimeograph machine — by giving them a leg up on the language of the poem, rather than throwing them in at the deep end or giving them a poor alternative to the language of the poem.

\section{Appendix: Semantically Consequential Variants}

The following list gives each line as in Corpus Christi, with significant variants following.

1.198 3e loueres and 3oure obseruances (Cp, Cl, H1) ... lewed obseruances (J, H3, Gg, R)

1.234 To seruen loue which so soon kanne ( $\mathrm{Cp}$ and minor mss.)

To scornen loue (J, Cl, H1, H3, G)

2.110 Do weye 3oure barbe and shewe 3oure face bare (Cp, Cl, H1) .. . 3oure wimpel (J, H3, Gg)

2.1081 And his vnworthynesse ay he excused (Cp, H3)

3.76 ffirst 3 ow to thonk and of 3oure lordshipe eke (Cp, J, H1, etc.)

$3.391 \quad$ Right as thy sclaue whider so thow wende (Cp, J, H, etc.) ... thy knaue $(\mathrm{Cl}, \mathrm{Gg})$

3.558 Ne lenger don hym after hire to cape (Cp, J, H1)

$$
\text { ... to gape }(\mathrm{Cl}, \mathrm{H} 3, \mathrm{Gg})
$$

3.1438-39 [These lines appear in one form in principal $\Gamma$ manuscripts and in another form in $\beta$; the difference would need a lengthier discussion than is possible here.]

3.1482 Syn that desir right now so biteth me (Cp, H1 [bitleth])

$$
\text { ... so streyneth (J, H3, Gg) }
$$

... so brenneth $(\mathrm{Cl})$

4.246 His eyen two for pite of herte (Cp, H1, H3, Gg)

... for piete of herte $(\mathrm{J})$

... for pite of his herte $(\mathrm{Cl})$ 
5.42 Than euer more in langour thus to crye (Cp, H1)

$$
\text { ... to drye ( } \mathrm{J}, \mathrm{Cl} \text {, etc.) }
$$

5.382 As Rauenes qualyn or shrichyng of thise owles (Cp, J [qualin], R [qualine]) ... qualm $(\mathrm{Cl}, \mathrm{H} 1, \mathrm{H} 3)$

$5.451 \quad$ For euere in on his herte pietous $(\mathrm{Cp} ; \mathrm{J} \& \mathrm{H} 1$ [pietus])

$$
\ldots \text { pitous }(\mathrm{Cl}, \mathrm{Gg}, \mathrm{H} 3)
$$

5.1598 Conceyued hath myn hertes pietee (Cp, J [piete]) ... pite $(\mathrm{Cl}, \mathrm{H} 1, \mathrm{H} 3$ [pete])

5.1809 Up to the holughnesse of the seuenthe spere $(\mathrm{Cl}, \mathrm{H} 1, \mathrm{H} 3)$

$\ldots$ viij spere $(\mathrm{J})$

... viijthe (R)

eyght (Caxton)

\section{Works Cited}

Adams, Robert. 1991. "Editing and the Limitations of the Durior Lectio". Yearbook of Langland Studies, 5: 7-15.

BARney, Stephen. 1987. Troilus and Criseyde [edited text and notes]. In The Riverside Chaucer, Edited by Larry D. Benson, Third Edition. Boston: Houghton Mifflin.

Brewer, D. S., introd. 1974. Geoffrey Chaucer, The Works, 1532: With Supplementary Material from the Editions of 1542, 1561, 1598, and 1602. London: Scolar Press.

Donaldson, E. T. 1958. Chaucer's Poetry: An Anthology for the Modern Reader. New York: Ronald Press.

Fisher, John. 1977. The Complete Poetry and Prose of Geoffrey Chaucer. New York: Holt, Rinehart and Winston.

Furnivall, F. J., ed. 1894. A Parallel-Text Print of Chaucer's Troilus and Criseyde. Chaucer Society Publications, First Series, 63, 64. London: Trübner. Rpt. New York: Johnson Reprint Corp, 1967.

- ed., 1894-95. Three More Parallel Texts of Chaucer's Troilus and Criseyde. Chaucer Society Publications, First Series, 87, 88. London: Oxford University Press. Rpt. New York: Johnson Reprint Corp., 1967.

Guthrie, Steven R. 1988. "Prosody and the Study of Chaucer: A Generative Reply to Halle-Keyser". Chaucer Review 23.1: 30-49.

- 2014. Chaucer's Troilus and Criseyde: A New Edition. agnesscott.edu/english. troilusandcriseyde.

Hanna, Ralph, 1992. "The Manuscripts and Transmission of Chaucer's Troilus". In The Idea of Medieval Literature. Edited by James DeAN and Christian ZACHER, 173-88. Newark: Univ. of Delaware Press.

Howard, Donald and James Dean, eds., 1976. Geoffrey Chaucer's Troilus and Criseyde and Selected Short Poems. New York: Signet Classics.

Interlinear Translations [of the Riverside Chaucer edition of The Canterbury Tales]. 2010. fas.harvard.edu/chaucer. 
Kane, George. 1960. Piers Plowman: The A-Version. London: Athlone Press.

Kroch alis, Jean. 1986. The Pierpont Morgan Manuscript M. 817: A Facsimile. Norman, OK: Pilgrim Books.

Murphy, Michael, n. d. Troilus and Criseyde by Geoffrey Chaucer: A Reader-Friendly Edition Put Into Modern Spelling. academic.brooklyn.cuny.edu/webcore/murphy/troilus.

Parkes, M. B. and Elizabeth Salter, introds. 1978. Troilus and Criseyde, Geoffrey Chaucer: A Facsimile of Corpus Christi College Cambridge MS 61. Cambridge: D. S. Brewer.

Robinson, F. N., ed. 1957. The Works of Geoffrey Chaucer. Second Edition. Boston: Houghton Mifflin.

Roncaglia, Aurelio, ed. 1941. Giovanni Boccaccio, Teseida delle nozze d'Emilia. Opere, Vol. III. Bari: Gius, Laterza \& Fili.

Root, R. K. 1914. The Manuscripts of Chaucer's Troilus. London: Oxford Univ. Press. 1916. The Textual Tradition of Chaucer's Troilus. Chaucer Society Publications, First Series, 99. New York: Oxford Univ. Press.

- ed. 1926. The Book of Troilus and Criseyde. Princeton: Princeton Univ. Press.

Scholarly Digital Editions, 2000. The Hengwrt Chaucer Digital Facsimile [advertisement]. www.sd-editions.com/hengwrt.

Tатцоск, John Strong Perry and Arthur G. Kennedy. 1927. A Concordance to the Complete Works of Geoffrey Chaucer and to the Romaunt of the Rose. Washington: Carnegie Institute.

Windeatt, Barry. 1982. "The Text of the Troilus". In Mary Salu, ed., Essays on Troilus and Criseyde, 1-22. London: D. S. Brewer.

—, ed., 2003. Geoffrey Chaucer: Troilus and Criseyde. New York: Penguin. 